\title{
The Metabolism of Erythropoietin in Patients with Anemia Due to Deficient Erythropoiesis *
}

\author{
Wendell F. Rosse and Thomas A. Waldmann \\ (From the Metabolism Service, National Cancer Institute, Bethesda, Md.)
}

Erythropoietin is a protein hormone, produced in response to anemia and anoxia, which stimulates erythropoiesis (1) and appears to play an integral role in the homeostasis of the circulating red cell mass. The factors stimulating the production of the hormone and the time relationships involved in its production have been studied extensively $(1,2)$, but little is known about the kinetics of its catabolism. Knowledge about metabolism of erythropoietin is necessary for full understanding of the dynamics of controlling red blood cell production.

The catabolism of specific proteins has been studied by labeling the pure protein with radioactive isotopes and following a rate of decline in serum or total body radioactivity (3). This technique requires that the protein being labeled be both completely pure and undamaged. Erythropoietin has not been purified; hence this technique cannot be used to study its metabolism.

If, however, the endogeneous production of a substance is stopped or markedly reduced, the characteristics of disappearance of the material from the serum may be followed to estimate the rate of catabolism. Transfusion is known to suppress the production of erythropoietin (4). Therefore, we have estimated the rate of catabolism of erythropoietin in patients with anemia, depressed erythropoiesis, and high serum erythropoietin titer by administering transfusions sufficient to raise the hemoglobin above $11 \mathrm{~g}$ per 100 $\mathrm{ml}$. The rate of disappearance of the hormone from the blood or urine was then determined. To estimate the contribution of urinary excretion to the metabolism of erythropoietin, we have

\footnotetext{
* Submitted for publication April 9, 1963; accepted February 24, 1964.

A preliminary report was presented at the Ninth Congress of The International Society of Hematology in Mexico City, September 8-15, 1962.
}

measured the renal clearance of the hormone in these and other patients.

\section{Materials and Methods}

Nine studies were done in 8 patients, all of whom had deficient erythropoiesis due to various causes (see $\mathrm{Ta}$ ble I). At the onset of each study, the hemoglobin concentration was between 6.0 and $8.0 \mathrm{~g}$ per $100 \mathrm{ml}$. Packed red blood cells from 1,500 to $2,000 \mathrm{ml}$ of blood were infused within 4 hours. At the termination of these initial transfusions and at appropriate intervals for several days thereafter, 20 to $25 \mathrm{ml}$ of blood was drawn under sterile conditions, the clot was allowed to retract, and the serum was removed and frozen until assayed for erythropoietin. Urine was collected in 8- or 24-hour samples for the period of the study and immediately frozen. During the period of study frequent determinations of hemoglobin concentration in whole blood were performed. The level of hemoglobin was maintained above $10.0 \mathrm{~g}$ per $100 \mathrm{ml}$ by further transfusions as necessary.

The samples of serum and urine were assayed by a previously published technique using transfused polycythemic mice (5). Female NIH strain mice weighing 18 to $22 \mathrm{~g}$ were given an intraperitoneal injection of an $80 \%$ suspension of homologous red blood cells on days 1 and $2(0.7 \mathrm{ml} \mathrm{each})$ and day $5(0.4 \mathrm{ml})$ of the assay. On days 5 and $6,0.5 \mathrm{ml}$ of serum or urine to be tested was injected subcutaneously, with 8 animals used to assay each material. On day $7,0.5 \mu \mathrm{c}$ of $\mathrm{Fe}^{50}$ citrate in 0.1 $\mathrm{ml} 0.15 \mathrm{M} \mathrm{NaCl}$ was injected intraperitoneally. On day 9 , the mice were bled by decapitation into tared bottles, which were reweighed, and the radioactivity due to $\mathrm{Fe}^{58}$ was determined using a well-type scintillation counter. The percentage of the injected dose of isotope present in each milliliter of whole blood was calculated using a dilute standard. Microhematocrits were taken at the time of decapitation; the results of those animals whose hematocrit was less than $60 \%$ were not used. Groups of 8 animals injected with saline instead of test material were included as negative controls with each group of assays. These animals had a uniformly low incorporation of radioiron into the peripheral blood, with from 0.10 to $0.20 \%$ of the injected dose incorporated per milliliter of blood.

A sample of known content of erythropoietin was also included with each group of assays. From the response to this standard and from the dose response curve previ- 
TABLE I

Clinical and laboratory data on patients studied

\begin{tabular}{|c|c|c|c|c|c|c|c|c|}
\hline \multirow[b]{3}{*}{ Patient } & \multirow[b]{3}{*}{ Age } & \multirow[b]{3}{*}{ Sex } & \multirow[b]{3}{*}{ Diagnosis } & \multicolumn{3}{|c|}{$\begin{array}{l}\text { Hemoglobin concentra- } \\
\text { tion during study }\end{array}$} & \multirow{3}{*}{$\begin{array}{l}\text { Retic- } \\
\text { ulo- } \\
\text { cytes }\end{array}$} & \multirow[b]{3}{*}{ Other comments } \\
\hline & & & & \multirow{2}{*}{$\begin{array}{l}\text { Before } \\
\text { trans- } \\
\text { fusion }\end{array}$} & \multicolumn{2}{|c|}{ After transfusion } & & \\
\hline & & & & & $\begin{array}{l}\text { Maxi- } \\
\text { mum }\end{array}$ & $\begin{array}{l}\text { Mini- } \\
\text { mum }\end{array}$ & & \\
\hline J.C. & & & & & $\mathrm{g} / 100 \mathrm{ml}$ & & $\%$ & \\
\hline $\begin{array}{l}\text { First study } \\
\text { Second study }\end{array}$ & 57 & $\mathbf{M}$ & Aplastic anemia & $\begin{array}{l}7.4 \\
6.2\end{array}$ & $\begin{array}{r}9.9 \\
12.0\end{array}$ & $\begin{array}{r}8.2 \\
10.7\end{array}$ & $\begin{array}{l}0 \\
0.6\end{array}$ & $\begin{array}{l}\text { Myelofibrosis } \\
10 \% \mathrm{Fe}^{59} \text { incorporation into red } \\
\text { blood cells } \\
\text { Serum } \mathrm{Fe}^{59} \text { disappearance } \mathrm{t}_{\xi}, 210 \\
\text { minutes }\end{array}$ \\
\hline J.F. & 56 & $\mathbf{M}$ & $\begin{array}{l}\text { Acute lymphocytic } \\
\text { leukemia }\end{array}$ & 7.8 & 12.3 & 10.7 & 0 & Few normoblasts in marrow \\
\hline E.F. & 72 & $\mathrm{~F}$ & Aplastic anemia & 6.4 & 12.9 & 11.1 & 0.1 & Myelofibrosis \\
\hline A.H. & 60 & $\mathbf{M}$ & $\begin{array}{l}\text { Chronic lymphocytic } \\
\text { leukemia }\end{array}$ & 6.4 & 12.0 & 11.2 & 0 & $\begin{array}{l}\text { No normoblasts in marrow; no incor- } \\
\text { poration of } \mathrm{Fe}^{59} \text { and glycine-2-C } \\
\text { into peripheral red blood cells }\end{array}$ \\
\hline R.C. & 20 & $\mathbf{M}$ & Acute leukemia & 7.2 & 13.1 & 11.8 & 0 & Few normoblasts in marrow \\
\hline J.O. & 35 & $\mathbf{M}$ & $\begin{array}{l}\text { Anaplastic carcinoma, } \\
\text { metastatic }\end{array}$ & 6.0 & 12.5 & 10.2 & 0.2 & \\
\hline D.H. & 10 & $\mathbf{M}$ & $\begin{array}{l}\text { Aplastic anemia } \\
\text { (? chloramphenicol } \\
\text { toxicity) }\end{array}$ & 6.8 & 10.4 & 10.0 & 0.9 & $\begin{array}{l}\text { Focal erythropoiesis in hypoplastic } \\
\text { marrow }\end{array}$ \\
\hline J.D. & 18 & $\mathbf{M}$ & Aplastic anemia & 7.4 & 11.6 & 10.2 & 0.1 & $\begin{array}{l}\text { Focal erythropoiesis in hypoplastic } \\
\text { marrow; <10\% of normal incor- } \\
\text { poration of glycine-2-C } 14 \text { into pe- } \\
\text { ripheral red blood cells }\end{array}$ \\
\hline
\end{tabular}

ously determined by standards of known potency, 1 the results of each assay could be expressed in units as defined by Goldwasser and White (6). With this assay, $0.03 \mathrm{U}$ of erythropoietin gave a response significantly different from the saline controls. The dose response curve is linear between 0.12 and $2.4 \mathrm{U}$ per ml. Samples with a titer above this maximal level were diluted with appropriate amounts of saline and reassayed. All samples in a given study were diluted by the same amount.

The rate of disappearance of serum erythropoietin was calculated by expressing the amount of erythropoietin present at a given time as percentage of the amount present at the conclusion of the initial transfusions. This value was plotted on the logarithmic ordinate of semilogarithmic paper against time in hours after the conclusion of the initial transfusions (Figure 1).

The line derived by the least squares method, with $x$ as time in hours and $y$ as the natural logarithm of the percentage of remaining activity, was calculated for these points. The coefficient of regression and the coefficient of correlation for this line were calculated. The half-time of disappearance $\left(t_{\frac{1}{2}}\right)$ was calculated from the

1 Standards distributed by the Hematology Study Section, National Institutes of Health. coefficient of regression according to the formula:

$$
\mathrm{t}_{\mathrm{j}}=\frac{\log _{\mathrm{e}} 0.5}{\text { coefficient of regression (slope) }} .
$$

Ninety-five per cent confidence limits were determined for each calculated $t_{1}$ from the standard error of the coefficient of regression.

The renal clearance of erythropoietin was determined in 6 patients in addition to the studies on patient J.C. Urine was collected for known periods of time (2 to 8 hours) and immediately frozen. Blood was drawn for serum samples at the mid-point of the collection period. All urine was assayed without further treatment.

\section{Results}

Nine studies in 8 patients are summarized in Table II. The erythropoietin titer at the onset of studies ranged from 4.3 to $0.43 \mathrm{U}$ per $\mathrm{ml}$ (average, $1.4 \mathrm{U}$ per $\mathrm{ml}$ ). In six of these studies, J.C. (second study), J.F., E.F., A.H., R.C., and J.O. (Figure 1), the level of serum erythropoietin at the conclusion was less than $7 \%$ of that at the onset, and in all six instances approached the 


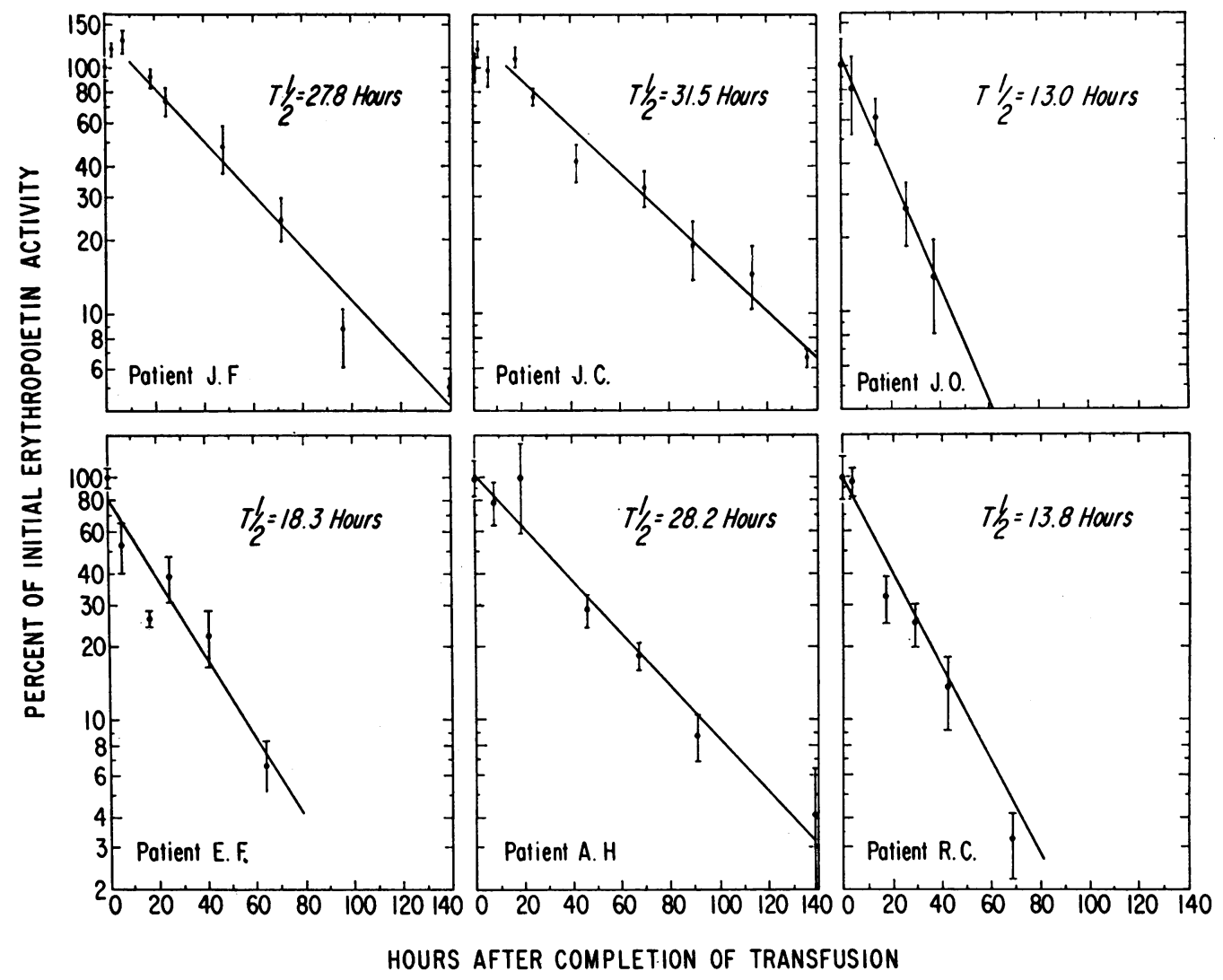

Fig. 1. The decline of SERUM erythropoietin levels after transfusion in 6 patients. Each point is the mean of the results from 6 to 8 animals used in the assay. The brackets indicate the standard error of the mean. The straight line is derived by the least squares method taking $x$ as time in hours and $y$ as $\log _{e}$ of the percentage of initial activity remaining.

minimal detectable concentration. In all cases, the declining portion of the graph of erythropoietin level against time could be approximated by a single exponential function. In three studies in 2 patients, this period of exponential decline was preceded by a lag phase of 10 to 18 hours during which the level of erythropoietin remained relatively constant. The coefficient of correlation of the calculated least squares line of all studies ranged from 0.840 to 0.993 and averaged 0.957 . The mean value of half-times of serum erythropoietin disappearance for all studies was 24.9 hours (range, 6.6 to 42.6 ).

In patient J.C., the rate of decline of urinary erythropoietin activity after transfusion was estimated. In Figure 2, the units of erythropoietin excreted in the urine per hour are plotted on semilogarithmic paper against the time after transfusion. The decline of erythropoietin level in the urine had the same characteristics as that in the serum. The renal clearance of erythropoietin was found in this and 6 other patients to range between $0.06 \mathrm{ml}$ per minute and $0.67 \mathrm{ml}$ per minute (Table III).

\section{Discussion}

The mean half-time of disappearance of serum erythropoietin in patients with erythroid hypoplasia in these studies was 24.9 hours, with a range between 6.6 and 42.6 hours. The reduction of erythropoietin titer in the serum after transfusion is the result of two processes: 1) the cessation of production and release into the serum and 2) the catabolism and loss of erythropoietin. Production of the hormone was clearly reduced to insignificant levels at some point during the course of the study in at least 6 cases, since less than $7 \%$ of the initial titer was present at the 
TABLE II

Summary of data on disappearance of erythropoietin from the serum after transfusion

\begin{tabular}{|c|c|c|c|c|c|c|c|c|}
\hline Patient & $\begin{array}{l}\text { Erythro- } \\
\text { poietin } \\
\text { titer at } \\
\text { start of } \\
\text { study }\end{array}$ & $\begin{array}{c}\text { Total } \\
\text { hours of } \\
\text { study }\end{array}$ & $\begin{array}{l}\text { \% of } \\
\text { initial } \\
\text { erythro- } \\
\text { poietin } \\
\text { at end } \\
\text { of study }\end{array}$ & $\underset{t}{\text { Survival }}$ & $\begin{array}{l}95 \% \text { con- } \\
\text { fidence limits } \\
\text { of } t_{t}\end{array}$ & $\begin{array}{l}\text { Coefficient of } \\
\text { regression }\end{array}$ & $\begin{array}{l}\text { Coefficient } \\
\text { of correlation }\end{array}$ & $\underset{\text { period }}{\mathbf{L a g}}$ \\
\hline J.C. & $U$ & & $\%$ & hours & & & & hours \\
\hline $\begin{array}{l}\text { First study } \\
\text { Second study }\end{array}$ & 1.7 & 52 & 55.1 & 42.4 & & -0.0164 & 0.848 & 10 \\
\hline $\begin{array}{l}\text { Serum } \\
\text { Urine }\end{array}$ & $\begin{array}{l}2.1 \\
0.36\end{array}$ & $\begin{array}{l}138 \\
108\end{array}$ & $\begin{array}{r}4.6 \\
12.0\end{array}$ & $\begin{array}{l}31.5 \\
29.8\end{array}$ & $\begin{array}{l}27.1-37.5 \\
25.7-35.5\end{array}$ & $\begin{array}{l}-0.0221 \\
-0.0233\end{array}$ & $\begin{array}{l}0.963 \\
0.983\end{array}$ & $\begin{array}{l}17 \\
16\end{array}$ \\
\hline J.F. & 1.1 & 142 & 5.0 & 27.8 & $23.5-32.9$ & -0.0249 & 0.978 & 12 \\
\hline E.F. & 1.4 & 64 & 6.6 & 18.3 & $12.8-23.9$ & -0.0378 & 0.953 & 0 \\
\hline A.H. & 0.52 & 163 & $<1.8$ & 28.2 & $23.9-34.5$ & -0.0246 & 0.983 & 0 \\
\hline R.C. & 0.43 & 69 & 3.0 & 13.8 & $12.2-15.9$ & -0.0502 & 0.993 & 0 \\
\hline J.O. & 1.3 & 66 & $<1.0$ & 13.0 & $12.2-14.9$ & -0.0517 & 0.981 & 0 \\
\hline D.H. & 4.3 & 10 & 34.6 & 6.6 & $5.6-7.8$ & -0.1052 & 0.991 & 0 \\
\hline J.D. & 0.47 & 93 & 17.7 & 42.6 & $30.2-72.5$ & -0.0162 & 0.925 & 0 \\
\hline
\end{tabular}

conclusion of the studies. If the production of the hormone were reduced to insignificant levels by, or shortly after, the completion of the transfusions, the decline in serum would reflect the rate of catabolism of the hormone. If both hormone production and noninstantaneous catabolism were taking place during the period of decline in serum level, a complex curve that could not be approximated by a single exponential function would result, except in the unlikely event that the decline in synthesis and the catabolism of the hormone were both exponential functions with the same rate constant. In the present stud-

TABLE III

Renal clearance rates of erythropoietin in patients with deficient erythropoiesis

\begin{tabular}{|c|c|c|c|c|c|}
\hline \multirow[b]{2}{*}{ Patient } & \multicolumn{2}{|c|}{$\begin{array}{c}\text { Erythropoietin } \\
\text { titers }\end{array}$} & \multirow{2}{*}{$\begin{array}{c}\text { Urine } \\
\text { volume }\end{array}$} & \multirow{2}{*}{$\begin{array}{l}\text { Time } \\
\text { of col- } \\
\text { lection }\end{array}$} & \multirow{2}{*}{$\begin{array}{c}\text { Renal } \\
\text { clear- } \\
\text { ance }\end{array}$} \\
\hline & Serum & Urine & & & \\
\hline & \multicolumn{2}{|c|}{$\begin{array}{c}\text { \% Fe incorpora- } \\
\text { tion } / \text { ml blood }\end{array}$} & $m l$ & minutes & $m l / \min$ \\
\hline D.F. & 5.14 & 5.11 & 60 & 115 & 0.52 \\
\hline A.H. & 3.00 & 1.22 & 495 & 480 & 0.42 \\
\hline F.LaB. & 3.10 & 0.21 & 195 & 220 & 0.06 \\
\hline \multirow{2}{*}{ J.Fr. } & 16.4 & 3.97 & 460 & 480 & 0.23 \\
\hline & 4.30 & 0.24 & 840 & 480 & 0.10 \\
\hline N.C. & 1.69 & 0.55 & 30 & 95 & 0.10 \\
\hline J.M. & 2.96 & 1.25 & 300 & 200 & 0.63 \\
\hline J.C.* & 15.64 & 6.14 & 820 & 480 & 0.67 \\
\hline J.C.† & & & & & 0.48 \\
\hline
\end{tabular}

* Single sample before transfusion.

$\dagger$ Mean of 7 determinations during the second erythropoietin_disappearance study. ies, a single exponential curve was seen in all cases (after a lag period in 2 patients), suggesting that a combination of production and noninstantaneous catabolism was not occurring during the period of decline of serum level. The presence of a lag phase may represent persistent

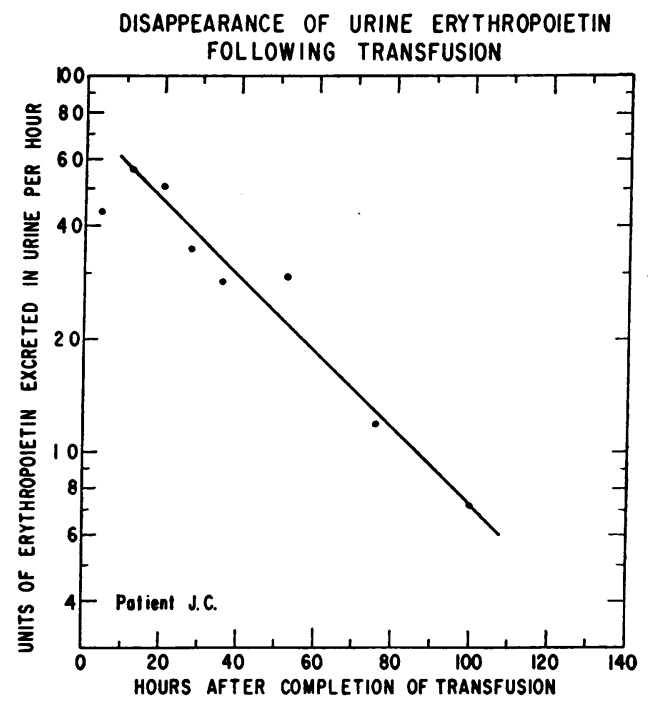

Fig. 2. THE DECLINE OF URINARY EXCRETION OF ERYTHROPOIETIN AFTER TRANSFUSION (patient J.C., second study). Each point is the mean of the results from 6 to 8 animals used in the assay. The erythropoietin excreted per hour is plotted against the mid-point of the period during which the urine was collected. The line is derived by the least squares method. 
production during the period immediately after the transfusions, but this does not invalidate the assumption of insignificant production during the period of exponential decline, the only period used to measure the survival $t_{1}$. On the other hand, it is theoretically possible that erythropoietin was almost instantaneously catabolized and that the decline seen in serum level was due to the gradual cessation of production. The studies of Stohlman and Brecher clearly show, however, that the catabolism of erythropoietin is not instantaneous in rats. In their studies, erythropoietin was injected into normal rats, and the rate of decline of the serum level was measured by bioassay (7). After a distribution phase, the serum level declined with a $t_{\frac{1}{2}}$ of 3 to 5 hours. This $t_{\frac{1}{2}}$ corresponded well with the decline of serum level of erythropoietin of rats brought from simulated altitude to normal oxygen tensions (8). This suggests that catabolism without significant persistent production is the major factor responsible for the decline in serum erythropoietin after the removal of the stimulus for erythropoietin production.

Although an order of magnitude for the survival $t_{1}$ of erythropoietin in the serum of patients with diminished erythropoiesis emerged, there was a considerable range in the values for different patients. The factors controlling the catabolism or loss of erythropoietin, as well as the sites of these processes, are not well defined. Loss of erythropoietin into the urine clearly represents one factor in the over-all metabolism of erythropoietin. The presence of erythropoietin in the urine has been previously well documented, and in fact urine from anemic patients and animals has been used as a source of the hormone (9-12). Since the kidney is the major site of production of erythropoietin (13), urinary erythropoietin may represent direct excretion into the urine by the producing cells or clearance of the serum or both. In the studies in patient J.C., the urinary excretion was roughly proportional to the serum level throughout the study time, suggesting that the urinary erythropoietin was derived from the serum, since, as discussed above, production had probably been suppressed by the transfusion early in the study. The renal clearance rates as calculated from these present studies (Table III) rep- resent minimal rates, as the most likely sources of error would tend to give lower values than the true values. Error due to loss of urine during collection and to loss of erythropoietin activity due to catabolic enzymes in the urine was reduced by careful supervision and immediate freezing of the samples. The urinary excretion of erythropoietin probably accounts for about $10 \%$ of the daily loss. This is calculated from an assumed total space of distribution of the hormone equal to that of albumin (about 7,000 ml), a total daily urine clearance of about $500 \mathrm{ml}$, and a $t_{\frac{1}{2}}$ of serum erythropoietin of about 24 hours.

In addition to urinary excretion, the liver and bone marrow have been suggested as sites of erythropoietin degradation. Perfusion of the isolated liver with blood containing the hormone has been shown to remove part of the biological activity (14). Erythropoietically active bone marrow is said to decrease the survival time of the hormone in rats (8) and man (15). In the present study there was no apparent correlation between the $t_{1}$ of erythropoietin survival and the renal or hepatic function of the patient, as evaluated by standard clinical tests, or the erythropoietin level at the onset of the studies or the hemoglobin levels obtained during the study. It is difficult to be certain that the degree of erythroid hypoplasia was the same in all patients. $\mathrm{Pa}$ tient D.H., with the shortest erythropoietin survival, had the highest reticulocyte count. The remaining patients, however, all had apparently comparable severe erythroid hypoplasia of the marrow, reticulocytopenia, and deficient incorporation of $\mathrm{Fe}^{59}$ or glycine-2- $\mathrm{C}^{14}$ into erythrocytes. Since these patients with marked erythroid hypoplasia had a fairly rapid rate of hormone degradation, organs other than the erythropoietic bone marrow must play an important role in the degradation of erythropoietin.

The knowledge that erythropoietin has an appreciable survival time may help in understanding certain observations about the kinetics of erythropoiesis. In animal experiments Erslev noted persistence of reticulocytosis for several days after a brief period of anemia (16). If colchicine was administered before the period of anemia, the onset of reticulocytosis was delayed for 2 days but was of equivalent degree. The persistence of 
erythropoietin produced during the anemic period could well explain the prolonged reticulocytosis in the first case and the initiation of erythropoiesis in the second case.

If erythropoiesis is depressed by direct toxic action upon the red cell precursors, as by radiation or antimetabolic drugs, the maximal depression of erythropoiesis as determined by alterations in the metabolism of iron or by reticulocytopenia occurs 4 to 6 days after the treatment (17-19). This probably represents the time required for the erythrocytic precursor cells present at the time of the treatment to mature and become erythrocytes. However, if erythropoiesis is depressed by suppressing the production of erythropoietin, as by transfusing anemic patients or by bringing patients polycythemic from chronic high altitude exposure to sea level, the maximal depression of erythropoiesis occurs 7 to 17 days after the transfusions or change in altitude (20-23). The additional time when compared to the first group probably represents in part the time for the erythropoietin present at the time of the transfusion or change in altitude to decline to insignificant levels.

\section{Summary}

1. Transfusions sufficient to raise the hemoglobin to nearly normal values were given to 8 patients with reduced or absent eyrthropoiesis in order to study the kinetics of disappearance of erythropoietin from the serum.

2. In all studies, the graph of erythropoietin titer against time is best approximated by a single exponential function.

3 . The mean half-time of survival of erythropoietin in the serum was 24.9 hours (range, 6.6 to 42.6 hours).

4. The renal clearance of erythropoietin ranged between 0.06 and $0.67 \mathrm{ml}$ per minute.

5. The report discusses the implications of the persisting erythropoietin in the serum for the understanding of the kinetics of erythropoiesis.

\section{References}

1. Gordon, A. S. Hemopoietine. Physiol. Rev. 1959, $39,1$.
2. Fried, W., L. F. Plzak, L. O. Jacobson, and E. Goldwasser. Studies on erythropoiesis. III. Factors controlling erythropoietin production. Proc. Soc. exp. Biol. (N. Y.) 1957, 94, 237.

3. Berson, S. A., R. S. Yalow, S. S. Schreiber, and J. Post. Tracer experiments with $\mathrm{I}^{131}$ labeled serum albumin: distribution and degradation studies. J. clin. Invest. 1953, 32, 746.

4. Gurney, C. W., and C. Pan. Studies on erythropoiesis. IX. Mechanism of decreased erythropoiesis in experimental polycythemia. Proc. Soc. exp. Biol. (N. Y.) 1958, 98, 789.

5. Rosse, W. F., T. A. Waldmann, and D. E. Houston. Erythropoietin assays using iron $^{50}$ incorporation into blood and spleen of the polycythemic mouse. Proc. Soc. exp. Biol. (N. Y.) 1962, 109, 836.

6. Goldwasser, E., and W. F. White. Purification of sheep erythropoietin. Fed. Proc. 1959, 18, 236.

7. Stohlman, F., Jr., and D. Howard. Humoral regulation of erythropoiesis. IX. The rate of disappearance of erythropoietine from the plasma in Erythropoiesis. New York, Grune \& Stratton, 1962, p. 120.

8. Stohlman, F., Jr., and G. Brecher. Humoral regulation of erythropoiesis. V. Relationship of plasma erythropoietine level to bone marrow activity. Proc. Soc. exp. Biol. (N. Y.) 1959, 100, 40.

9. Van Dyke, D. C. Sources and properties of human urinary erythropoietin in Hæmopoiesis. Boston, Little, Brown, 1960, p. 397.

10. Gordon, A. S. Humoral influences on blood cell formation and release in Hæmopoiesis. Boston, Little, Brown, 1960, p. 325.

11. Prentice, T. C., and E. A. Mirand. Some aspects of the relationship between plasma and urine erythropoietin. Proc. Soc. exp. Biol. (N. Y.) 1962, 109, 414.

12. Naets, J. P. Le role du rein dans l'erythropoiese. Acta clin. belg. 1960, 15, 361.

13. Jacobson, L. O., E. Goldwasser, W. Fried, and L. F. Plzak. Studies on erythropoiesis. VII. The role of the kidney in the production of erythropoietin. Trans. Ass. Amer. Phycns 1957, 70, 305.

14. Burke, W. T., and B. S. Morse. Studies on the production and metabolism of erythropoietin in rat liver and kidney in Erythropoiesis. New York, Grune \& Stratton, 1962, p. 111.

15. Hammond, G. D., and A. Ishikawa. The rate of disappearance of erythropoietin following transfusion of severely anemic patients in Erythropoiesis. New York, Grune \& Stratton, 1962, p. 128.

16. Erslev, A. S. The effect of anemic anoxia on the cellular development of nucleated red cells. Blood 1959, 14, 386.

17. Condit, P. T. Studies on the folic acid vitamins. II. The acute toxicity of amethopterin in man. Cancer (Philad.) 1960, 13, 222. 
18. Condit, P. T., N. I. Berlin, and D. G. Nathan. Studies on the folic acid vitamins. VI. The effect of amethopterin on erythropoiesis in man. Cancer (Philad.) 1960, 13, 245.

19. Levin, J., J. R. Andrews, and N. I. Berlin. The effects of total body irradiation on some aspects of human iron metabolism. J. clin. Invest. 1961, 40, 649.

20. Reynafarje, C., R. Lozano, and J. Valdivieso. The polycythemia of high altitudes: iron metabolism and related aspects. Blood 1959, 14, 433.
21. Huff, R. L., J. H. Lawrence, W. E. Siri, L. R. Wasserman, and T. G. Hennessy. Effect of changes in altitude on hematopoietic activity. Medicine (Baltimore) 1951, 30, 197.

22. Chaplin, H., Jr., H. G. Keitel, and R. E. Peterson. Hematologic observations on patients with sickle cell anemia sustained at normal hemoglobin levels by multiple transfusions. Blood 1956, 11, 834.

23. Donegan, C. C., Jr., W. A. MacIlwaine, and B. S. Leavell. Hematologic studies on patients with sickle cell anemia following multiple transfusions. Amer. J. Med. 1954, 17, 29. 